\title{
IMPLEMENTASI KEBIJAKAN PENATAAN DAN PEMERATAAN BERDASARKAN BEBAN KERJA GURU SMA NEGERI DI TEMBILAHAN KOTA KECAMATAN TEMBILAHAN KABUPATEN INDRAGIRI HILIR
}

\author{
Ere Mardella Arbiani ${ }^{1)}$ \\ Azhar ${ }^{2)}$ \\ Mahdum ${ }^{3)}$ \\ 1)Post Graduate Student of Riau University \\ ${ }^{2)}$ Lecturer of Education Management Study Programme PPs University of Riau \\ ${ }^{3)}$ Lecturer of Education Management Study Programme PPs University of Riau
}

\begin{abstract}
This research was aimed at finding out the structuring and equality policies of the teaching loads of the state Senior High School (SMAN) teachers of Tembilahan Kota, Indragiri Hilir District. The data were gathered through observation, interview and documentation. The informants of the research were employees of the District Education Office, school supervisors, head teachers, and a number of teachers in the Sub-district of Tembilahan Kota. The data analysis used in this study was policy analysis since the research employed the qualitative approach.The findings of the research indicated that (1) the program planning of the structuring and equality of the teachers' teaching loads has been implemented. (2) In its implementation, however, there were teachers who could not have 24 teaching hours in a week. (3) The implementation of the planned program of the structuring and the equality of the teachers' teaching loads was running smoothly, but not yet as maximal as expected.
\end{abstract}

Key words: Restructuring, equality, teacher teaching loads

ABSTRAK: Penelitian ini bertujuan untuk mengetahui penataan dan pemerataan guru berdasarkan beban kerja guru SMA Negeri di Tembilahan Kota Kecamatan Tembilahan Kabupaten Indragiri Hilir. Informan yang diwawancarai dalam penelitian ini adalah pegawai Dinas Pendidikan, Pengawas Sekolah, Kepala Sekolah dan beberapa guru di Tembilahan Kota. Instrumen yang digunakan berbentuk observasi, wawancara dan dokumentasi. Analisis data yang digunakan untuk memaparkan data penataan dan pemerataan guru berdasarkan beban kerja guru SMA Negeri di Tembilahan Kota Kecamatan Tembilahan Kabupaten Indragiri Hilir adalah analisis kebijakan. Hasil penelitian menunjukkan bahwa pertama, perencanaan program penataan dan pemerataan berdasarkan beban kerja guru SMA Negeri di Tembilahan Kota Kecamatan Tembilahan Kabupaten Indragiri Hilir telah dilaksanakan. Kedua, pada tahap pelaksanaan penataan dan pemerataan berdasarkan beban kerja guru SMA Negeri di Tembilahan Kota telah terlaksana, namun masih ada beban mengajar yang tidak mencukupi 24 jam tatap muka perminggu. Ketiga, hasil pelaksanaan program penataan dan pemerataan berdasarkan beban kerja guru SMA Negeri di Tembilahan Kota Kecamatan Tembilahan Kabupaten Indragiri Hilir sudah berjalan dengan baik. Namun belum maksimal seperti yang diharapkan.

Kata Kunci :Penataan, Pemerataan, Beban Kerja Guru 


\section{PENDAHULUAN}

Perubahan dari zaman ke zaman sangatlah cepat. Indonesia adalah sebuah negara berkembang di suatu kawasan Asia yang lebih tepatnyaAsia Tenggara yang juga masih termasuk dalam kawasan yang berkembang. Di dalam sebuah negara dan kawasan yang berkembang dan ingin menjadi negara maju maka Indonesia harus memiliki sumber kekayaan alam dan sumber daya manusia. Namun, sumber kekayaan alam tidak akan berguna tanpa adanya kualitas sumber daya manusianya sendiri. Oleh sebab itu, indonesia harus meningkatkan kualitas sumberdaya manusia.

Salah satu cara untuk meningkatkan sumber daya manusia Indonesia adalah dengan cara meningkatkan kualitas pendidikan di Indonesia. Untuk saat ini, pendidikan masih sedikit menyedihkan karena masih ada beberapa hal yang harus diperbaiki. Salah satu yang menjadi kelemahan pendidikan di Indonesia adalah tidak meratanya guru yang tersebar. Baik di kota besar maupun di desa-desa.

Pemerintah ingin meningkatkan mutu pendidikan. Namun, faktor penghambat selalu ada, sehingga pemerintah juga kesulitan untuk merealisasikan keinginannya agar di indonesia memiliki pendidikan yang berkualitas. Keinginan Kementerian Pendidikan Nasional (Kemendiknas) untuk melakukan pemerataan guru di seluruh Indonesia juga terganjal otonomi daerah (otoda) yang dimiliki. Pemerintah sebenarnya sudah mengajukan usulan penambahan guru ke pemerintah daerah yang kekurangan. Namun ada juga pemerintah daerah yang langsung mengajukan permintaan ke pusat. Maka dari itu harus ada kesepakatan terlebih dulu dengan pemerintah daerah. Karena, di era otonomi daerah seperti ini Kemendiknas tidak dapat melakukan apapun untuk menempatkan guru tanpa persetujuan pemerintah daerah.

Guru atau disebut juga dengan pendidik dalam bahasa arab ialah mu'allim. Guru itu adalah seorang yang memiliki pekerjaan yaitu mengajar dan mendidik. Seperti yang tertulis dalam KBBI (2008:469) menjelaskan, “Guru adalah orang yang pekerjaannya (mata pencahariannya, profesinya) mengajar”. Sedangkan menurut peraturan bersama lima menteri (menteri pendidikan, menteri pendayagunaan, menteri aparatur negara dan reformasi birokrasi, menteri keuangan, menteri dalam negeri, dan menteri agama) menjelaskan bahwa guru adalah pendidik profesional dengan tugas utama mendidik, mengajar, membimbing, mengarahkan, melatih, menilai dan mengevaluasi peserta didik pada tingkat anak usia dini jalur pendidikan formal, pendidikan dasar dan menengah.

UU Nomor 14 Tahun 2005 tentang Guru dan Dosen disahkan oleh DPR bersama Presiden pada 30 Desember 2005. Dan, diundangkan di Jakarta pada tanggal yang sama dalam Lembaran Negara RI Tahun 2005 Nomor 157. Dalam bab IV tentang Kualifikasi, Kompetensi, dan Sertifikasi pasal 8, Guru wajib memiliki kualifikasi akademik. kompetensi, sertifikat pendidik, sehat jasmani dan rohani, serta memiliki kemampuan untuk mewujudkan tujuan pendidikan nasional.

Guru yang profesional harus tahu dan mengikuti peraturan yang ada. Salah satunya mengenai jumlah jam wajib mengajar. Jam wajib mengajar seorang guru adalah 24 jam tatap muka perminggu berdasarkan bidang tugas yang diampu. Namun pada kenyataannya masih ada guru yang kekurangan beban mengajar seperti yang ditetapkan. Itu dikarenakan tidak meratanya guru yang tersebar di sekolah-sekolah.

Implementasi berasal dari bahasa Inggris yaitu to implement yang berarti mengimplementasikan. Implementasi merupakan penyediaan sarana untuk melaksanakan sesuatu yang menimbulkan dampak atau akibat terhadap sesuatu. Implementasi juga merupakan suatu tindakan atau pelaksanaan dari sebuah rencana yang sudah disusun secara matang dan terperinci. Implementasi biasanya dilakukan setelah perencanaaan sudah dianggap fix. Implementasi ini tidak hanya aktivitas, tetapi suatu kegiatan yang direncanakan dan dilaksanakan dengan serius dengan mengacu pada norma-norma tertentu mencapai tujuan kegiatan. Oleh karena itu, pelaksanaan tidak berdiri sendiri tetapi 
dipengaruhi oleh objek berikutnya. Seperti yang dijelaskan oleh Usman(2002: 70), “Implementasi adalah bermuara pada aktivitas, aksi, tindakan, atau adanya mekanisme suatu sistem. Implementasi bukan sekedar aktivitas, tetapi suatu kegiatan yang terencana dan untuk mencapai tujuan kegiatan”.

Implementasi tidak hanya direncanakan namun implementasi juga sebagai pengembangan kebijakan untuk menyempurnakan. Sejalan dengan pendapat Harsono (2002:67) menjelaskan, "Implementasi adalah suatu proses untuk melaksanakan kebijakan menjadi tindakan kebijakan dari politik ke dalam administrasi. Pengembangan kebijakan dalam rangka penyempurnaan suatu program”.

Implementasi menurut Mazmanian dan Sabatier, "Implementasi merupakan pelaksanaan dari kebijakan dasar hukum juga berbentuk dalam bentuk perintah atau keputusan, atau putusan pengadilan. Proses pelaksanaan berlangsung setelah sejumlah tahapan seperti tahapan pengesahan undang-undang, dan kemudian output dalam bentuk pelaksanaan keputusan kebijakan, dan seterusnya sampai kebijakan korektif yang bersangkutan.

Implementasi menurut Setiawan (2004:39) menjelaskan, "Implementasi adalah perluasan aktivitas yang saling menyesuaikan proses interaksi antara tujuan dan tindakan untuk mencapainya serta memerlukan jaringan pelaksana, birokrasi yang efektif”.

Pendapat Cleaves yang dikutip (dalam Wahab 2008;187), yang secara tegas menyebutkan bahwa: Implementasi itu mencakup "Proses bergerak menuju tujuan kebijakan dengan cara langkah administratif dan politik". Keberhasilan atau kegagalan implementasi sebagai demikian dapat dievaluasi dari sudut kemampuannya secara nyata dalam meneruskan atau mengoperasionalkan program-program yang telah dirancang sebelumya.

Sofian Effendi (2000) menyatakan bahwa "implementasi kebijakan adalah proses pelaksanaan kebijakan atau menerapkan kebijakan setelah kebijakan itu disahkan untuk menghasilkan outcome yang diinginkan”. Berarti tidak hanya mengandung maksud terjadinya suatu proses tunggal atau berdiri sendiri, tapi ada proses lain yang dilakukan dalam upaya persiapan implementasi dan proses "yang sebenarnya” dari implementasi kebijakan itu sendiri.

Menurut Friedrich (dalam Wahab 2008: 3) Kebijakan adalah suatu tindakan yang mengarah pada tujuan yang diusulkan oleh seseorang, kelompok atau pemerintah dalam lingkungan tertentu sehubungan dengan adanya hambatanhambatan tertentu seraya mencari peluangpeluang untuk mencapai tujuan atau mewujudkan sasaran yang diinginkan.

Dari uraian di atas, dapat disimpulkan bahwa implementasi kebijakan adalah suatu proses melaksanakan atau menerapkan kebijakan melalui serangkaian tindakan operasional untuk menghasilkan outcome yang diinginkan.

Jenkins (1986) mengatakan studi implementasi adalah studi perubahan. Bagaimana perubahan itu terjadi, bagaimana kemungkinan perubahan bisa dimunculkan.

Menurut Van Meter dan Van Horn (1975), implementasi memiliki sifat diataranya: implementasi akan dipengaruhi oleh sejauh mana kebijakan menyimpang dari kebijakan-kebijakan sebelumnya, proses implementasi akan dipengaruhi oleh jumlah perubahan organisasi yang diperlukan.

Selain itu menurut Christopher Hood (1991), agar implementasi sempurna ada lima syarat atau kondisi, yakni: (1) implementasi ideal itu akan ditegakkan dan tujuan ditentukan, (2) orang akan melaksanakan apa yang diminta dan diperhatikan, (3) harus ada komunikasi yang sempurna di dalam dan diantara organisasi, dan (4) tidak ada tekanan waktu. Dengan kata lain, bahwa sifat-sifat implementasi selalu dipengaruhi oleh perubahan kebijakan-kebijakan yang telah diterapkan sebelumnya serta dimana implementasi itu akan diterapkan.

\section{Model-model Implementasi Kebijakan}

Ada sepuluh model dalam studi implementasi kebijakan, yaitu sebagai berikut: 
1. Model Van Meter dan Van Horn, Model pertama adalah model yang paling klasik, yakni model yang diperkenalkan oleh Donald Van Meter dan Carl Van Horn (1975). Model ini mengandaikan bahwa implementasi kebijakan berjalan seara linear dari kebijakan publik, implementator, dan kinerja kebijakan publik.

2. Model Mazmanian dan Paul A. Sabatier, Model yang kedua adalah model yang dikembangkan Daniel Mazmanian dan Paul A. Sabatier (1983) yang mengemukakan bahwa implementasi adalah upaya melaksanakan keputusan kebijakan. Model Mazmanian dan Sabatier disebut Model Kerangka Analisis Implementasi (a framework for implementation analysis).

3. Model Hogwood dan Gunn, Model ketiga adalah Model Brian W. Hogwood dan Lewis A. Gunn (1978), untuk dapat mengimplementasikan kebijakan secara sempurna, maka diperlukan beberapa persayaratan tertentu.

4. Model Goggin, Malcolm Goggin, Ann Bowman, dan James Lester mengembangkan apa yang disebutnya sebagai "communication model” untuk implementasi kebijakan yang disebutnya sebagai "generasi ketiga model implementasi kebijakan” (1990). Goggin dan kawankawan bertujuan mengembangkan sebuah model implementasi kebijakan yang lebih ilmiah dengan mengedepankan pendekatan metode penelitian dengan adanya variabel independen, intervening, dan dependen, dan meletakkan komunikasi sebagai penggerak dalam implementasi kebijakan.

5. Model Grindle, Model Implementasi Kebijakan Publik yang dikemukakan Grindle (1980:7) menuturkan bahwa Keberhasilan proses implementasi kebijakan sampai kepada tercapainya hasil tergantung kepada kegiatan program yang telah dirancang dan pembiayaan cukup, selain dipengaruhi oleh Content of Policy (isi kebijakan) dan Contex of Implementation (konteks implementasinya).
6. Model Elmore, dkk. Model yang disusun Richard Elmore (1979), Michael Lipsky (1971), dan Benny Hjern dan David O’Porter (1981). Model ini dimulai dari mengidentifikasikan jaringan aktor yang terlibat dalam proses pelayanan dan menanyakan kepada mereka: tujuan, strategi, aktivitas, dan kontak-kontak yang mereka miliki.

7. Model Edward, menegaskan bahwa masalah utama administrasi publik adalah lack of attention to implementation. Dikatakannya, without effective implementation the decission of policymakers will not be carried out successfully. Edward menyarankan untuk memperhatikan empat isu pokok agar implementasi kebijakan menjadi efektif, yaitu communication, resource, disposition or attitudes, dan beureucratic structures.

8. Model Nakamura dan Smallwood, mengambarkan proses implementasi kebijakan secara detail. Begitu detailnya, sehingga model ini relatif relevan diimplementasikan pada semua kebijakan.

9. Model Jaringan, Model ini memehami bahwa proses implementasi kebijakan adalah sebuah complex of interaction processes di antara sejumlah besar aktor yang berada dalam suatu jaringan (network) aktor-aktor yang independen. Interaksi di antara para aktor dalam jaringan tersebutlah yang akan menentukan bagaimana implementasi harus dilaksanakan, permasalahan-permasalahan yang harus dikedepankan, dan diskresidiskresi yang diharapkan menjadi bagian penting di dalamnya.

10. Model Matland, Richard Matland (1995) mengembangkan sebuah model yang disebut dengan Model Matriks Ambiguitas-Konflik yang menjelaskan bahwa implementasi secara admiministratif adalah implementasi yang dilakukan dalam keseharian operasi birokrasi pemerintahan. Kebijakan di sini memiliki ambiguitas atau kemenduaan yang rendah dan konflik yang rendah. Implementasi secara politik adalah implementasi yang perlu dipaksakan secara 
politik, karena, walaupun ambiguitasnya rendah, tingkat konfliknya tinggi. Implementasi secara eksperimen dilakukan pada kebijakan yang mendua, namun tingkat konfilknya rendah. Implementasi secara simbolik dilakukan pada kebijakan yang mempunyai ambiguitas tinggi dan konflik yang tinggi.

Pada penelitian ini, peneliti menggunakan model implementasi yang dikembangkan oleh Daniel Mazmanian dan Paul A. Sabatier (1983) yang mengemukakan bahwa implementasi adalah upaya melaksanakan keputusan kebijakan. Model Mazmanian dan Sabatier disebut Model Kerangka Analisis Implementasi (a framework for implementation analysis).

Mazmanian-Sabatier

mengklasifikasikan proses implementasi kebijakan ke dalam tiga variabel, yaitu:

1. Variabel Independen

Mudah-tidaknya masalah dikendalikan yang berkenaan dengan indikator masalah teori dan teknis pelaksanaan, keragaman objek, dan perubahan seperti apa yang dikehendaki.

\section{Variabel Intervening}

Diartikan sebagai kemampuan kebijakan untuk menstrukturkan proses implementasi dengan indikator kejelasan dan konsistensi tujuan, dipergunakannya teori kausal, ketepatan alokasi sumber dana, keterpaduan hirarkis di antara lembaga pelaksana, aturan pelaksana dari lembaga pelaksana, dan perekrutan pejabat pelaksana yang memiliki keterbukaan kepada pihak luar, variabel di luar kebijakan yang mempengaruhi proses implementasi yang berkenaan dengan indikator kondisi sosioekonomi dan teknologi, dukungan publi, sikap dan risorsis konstituen, dukungan pejabat yang lebih tinggi, serta komitmen dan kualitas kepemimpinan dari pejabat pelaksana.

\section{Variabel Dependen}

Yaitu tahapan dalam proses implementasi kebijakan publik dengan lima tahapan, yang terdiri dari: pertama, pemahaman dari lembaga/ badan pelaksana dalam bentuk disusunnya kebijakan pelaksana. Kedua, kepatuhan objek. Ketiga, hasil nyata. Ke-empat, penerimaan atas hasil nyata. Terakhir, kelima, tahapan yang mengarah pada revisi atas kebijakan yang dibuat dan dilaksanakan, baik sebagian maupun keseluruhan kebijakan yang bersifat mendasar.

\section{Konsep Penataan}

Penataan merupakan suatu proses untuk menata ataupun menyusun. Kata dasar penataan adalah tata. Dalam Kamus Besar Bahasa Indonesia, "Penataan yaitu proses, cara, perbuatan menata; pengaturan; penyusunan". (KBBI, 2008:1410).

Penataan guru merupakan salah satu perencanaan yang bertujuan untuk memperbaiki penempatan guru sesuai dengan kebutuhan di setiap masing-masing sekolah. Penataan yang baik dan benar akan membantu keberhasilan untuk memeratakan guru.

\section{Konsep Pemerataan}

Pemerataan adalah suatu usaha untuk meratakan. Kata dasar dari pemerataan adalah rata. Dalam Kamus Besar Bahasa Indonesia, "Rata adalah sama-sama memperoleh jumlah yang sama" sedangkan "Pemerataan adalah proses, perbuatan memeratakan”. (KBBI,2008:1147).

\section{Konsep Beban Kerja Guru}

Beban kerja merupakan beban aktivitas fisik, mental, sosial yang diterima oleh seseorang yang harus diselesaikan dalam waktu tertentu, sesuai dengan kemampuan fisik, maupun keterbatasan pekerja yang menerima beban tersebut. Seperti yang dijelaskan oleh Nurmianto (2003), "Beban kerja adalah sekumpulan atau sejumlah kegiatan yang harus diselesaikan dalam jangka waktu tertentu.

\section{Peraturan Pemenuhan Beban Kerja Guru}

Berdasarkan permendikbud nomor 4 tahun 2015, tidak semua guru mata pelajaran dapat diakui kegiatan ekuivalensinya, akan tetapi hanya guru yang mengampu pada mata pelajaran yang terkena dampak perubahan beban belajar 
peserta didik dalam struktur kurikulum dari Kurikulum 2013 ke Kurikulum Tahun 2006. Adapun lima kegiatan yang dapat dikategorikan sebagai ekuivalensi jam tata muka adalah:

1. Menjadi wali kelas,

2. Membina OSIS,

3. Menjadi guru piket,

4. Membina kegiatan ekstrakurikuler,

5. Menjadi tutor Paket A, Paket B, Paket C, Paket C Kejuruan, atau program pendidikan kesetaraan.

\section{Pengertian ekuivalensi}

Berdasarkan permendikbud nomor 4 tahun 2015, “Ekuivalensi adalah penghargaan kegiatan selain mengajar di kelas untuk di akui sebagai jam pelajaran”.

\section{Tujuan Ekuivalensi}

Tujuannya adalah untuk mengatasi permasalahan guru yang bersertiûkat pendidik yang mengajar mata pelajaran tertentu pada rombongan belajar di SMP/SMA/SMK yang sebelumnya menggunakan kurikulum 2013, kemudian menggunakan kurikulum tahun 2006 untuk memenuhi beban mengajar minimal 24 jam tatap muka per minggu.

\section{Peraturan Bersama Lima Menteri Tentang Penataan dan Pemerataan Guru}

Penataan dan pemerataan guru PNS diatur dalam peraturan bersama lima menteri terkait dengan proses penataan ulang rasio guru PNS yang ada di seluruh Indonesia. Selain itu juga peraturan bersama lima menteri tentang penataan dan pemerataan guru PNS memiliki tujuan untuk memeratakan pelayanan dan kualitas pendidikan formal di Indonesia. Kebijakan ini diundangkan pada tahun 2011 dan berlaku secara efektif diseluruh daerah pada tahun 2012. Penataan dan pemerataan guru PNS dilakukan di daerah yang mengalami kekurangan dan kelebihan guru. Untuk selanjutnya disusun perencanaan tentang penataan ini.

Menurut peraturan bersama lima menteri tentang penataan dan pemerataan guru PNS, pelaksana utama dari penataan dan pemerataan guru PNS di wilayah kabupaten/kota adalah Bupati/Walikota, namun untuk mekanisme pelaksanaan di lapangan dilakukan oleh Dinas Pendidikan kabupaten/kota tersebut. Dalam melakukan penataan dan pemerataan guru PNS antar satuan pendidikan, antar jenjang, dan antar jenis pendidikan, pemerintah kabupaten/kota memiliki tugas sebagai berikut:

1. Menyusun produk hukum dalam bentuk peraturan Bupati/Walikota atau produk hukum lainnya terkait penataan dan pemerataan guru PNS yang merujuk pada peraturan bersama.

2. Sosialisasi program penataan dan pemerataan guru PNS di wilayah kabupaten/ kota.

3. Verifikasi data guru dan analisis kebutuhan guru TK, SD, SMP, SMA dan SMK di setiap satuan pendidikan di wilayah kabupaten/kota.

4. Penyediaan peta guru yang menginformasikan tentang kelebihan dan/ atau kekurangan guru PNS di wilayah kabupaten/kota dengan tembusan disampaikan kepada Badan Kepegawaian Daerah (BKD).

5. Pemindahan guru PNS antar satuan pendidikan.

6. Penyediaan dana pemindahan guru PNS antar satuan pendidikan di wilayah kabupaten/kota.

Sedangkan perencanaan kebutuhan guru berdasarkan petunjuk teknis peraturan bersama lima menteri ini adalah sebagai berikut:

1. Prasyarat

Perencanaan kebutuhan guru dilakukan berdasarkan laporan dari satuan pendidikan tentang jumlah guru sesuai dengan jenis guru, jumlah peserta didik, jumlah rombongan belajar, jumlah jam setiap mata pelajaran yang mengacu pada struktur kurikulum, dan disesuaikan dengan jenis program yang dibuka (untuk SMA dan SMK) ke Dinas Pendidikan kabupaten/kota. Khusus untuk PLB, perencanaan kebutuhan guru di sampaikan ke Dinas Pendidikan provinsi. 


\section{Ruang Lingkup}

Perencanaan guru meliputi kegiatan perumusan kebutuhan jenis dan jumlah guru. Perumusan jenis guru dilakukan pada tingkat nasional, sedangkan perhitungan jumlah guru berdasarkan jenisnya dilakukan pada tiap-tiap satuan pendidikan untuk digabung menjadi kebutuhan guru pada tingkat kabupaten/kota. Kebutuhan guru dari setiap kabupaten/kota digunakan untuk menghitung kebutuhan guru pada tingkat provinsi dan tingkat nasional.

\section{Jenis Guru}

Berdasarkan sifat, tugas dan kegiatannya, guru digolongkan kedalam 3 (tiga) jenis sebagai berikut:

a. Guru kelas adalah guru yang mempunyai tugas, tanggungjawab, wewenang dan hak secara penuh dalam proses pembelajaran seluruh mata pelajaran di kelas tertentu di TK/TKLB dan SD/SDLB dan satuan pendidikan formal yang sederajat.

b. Guru mata pelajaran adalah guru yang mempunyai tugas, tanggungjawab, wewenang, dan hak secara penuh dalam proses pembelajaran pada 1 (satu) mata pelajaran tertentu pada satuan pendidikan formal pada jenjang pendidikan dasar (SD/ SDLB, SMP/SMPLB) termasuk guru mata pelajaran pendidikan jasmani olahraga dan kesehatan, dan guru pendidikan agama serta pendidikan menengah (SMA, SMALB, SMK). Guru mata pelajaran pada SMK dikelompokkan menjadi guru normatif/ adaptif dan guru produkif. Jenis guru muatan lokal ditentukan oleh masing-masing satuan pendidikan berdasarkan kebijakan tiap provinsi/kabupaten/kota.

c. Guru bimbingan dan konseling/konselor adalah guru yang mempunyai tugas, tanggung jawab, wewenang, dan hak secara penuh dalam kegiatan bimbingan dan konseling terhadap sejumlah peserta didik satuan pendidikan formal pada jenjang pendidikan dasar (SMP/SMPLB) dan pendidikan menengah (SMA/SMALB dan SMK).
Selanjutnya, optimalisasi pemenuhan kebutuhan guru terhadap perbedaan antara jumlah guru yang tersedia dengan jumlah guru yang dibutuhkan sesuai dengan jenisnya baik tingkat satuan pendidikan maupun ditingkat kabupaten/kota menggambarkan kondisi kekurangan dan/atau kelebihan jenis guru.

\section{Guru Kelas}

a. Kekurangan guru kelas dapat diatasi dengan cara sebagai berikut:

1) Menerima guru pindahan dari satuan pendidikan lain dari kabupaten/kota yang sama atau kabupaten/kota yang lain.

2) Pengangkatan/rekruitmen guru baru.

3) Pembelajaran kelas rangkap untuk daerah atau wilayah tertentu sesuai ketentuan yang berlaku.

b. Kelebihan guru kelas dapat diatasi dengan cara sebagai berikut:

1) Memindahkan guru dari satuan pendidikan lain dari kabupaten/kota yang sama atau kabupaten/kota yang lain.

2) Alih fungsi/profesi guru, sesuai dengan ketentuan yang berlaku.

3) Pensiun dini, sesuai dengan ketentuan yang berlaku.

\section{Guru Mata Pelajaran}

Kekurangan dan/atau kelebihan guru mata pelajaran dapat diatasi dengan cara sebagai berikut:

a. Menerima atau memindahkan guru mata pelajaran tertentu dari satuan pendidikan ke satuan pendidikan lain di kabupaten/kota yang sama atau kabupaten/kota yang lain.

b. Memindahkan guru mata pelajaran tertentu ke mata pelajaran lain yang bukan bidangnya dengan mempertimbangkan kedekatan latar belakang pendidikan guru yang bersangkutan dengan mata pelajaran yang akan diampu, yang dikenal dengan istilah alih fungsi/profesi.

c. Pengangkatan/rekruitmen guru baru.

d. Alih fungsi/profesi, dilakukan bagi guru yang jumlahnya berlebihan untuk mengisi 
kekurangan jenis guru tertentu. Guru alih fungsi/profesi harus mengikuti pendidikan/ pelatihan/penataran yang direncanakan untuk keperluan tersebut agar mendapatkan kompetensi professional pada mata pelajaran baru yang akan diampu.

3. Guru Bimbingan Konseling

a. Kekurangan guru BK dapat diatasi dengan cara sebagai berikut:

1) Menerima guru pindahan dari satuan pendidikan lain dari kabupaten/kota yang sama atau kabupaten/kota yang lain.

2) Pengangkatan/rekruitmen guru baru.

b. Kelebihan guru BK dapat diatasi dengan cara sebagai berikut:

1) Memindahkan guru dari satuan pendidikan tertentu dari kabupaten/kota yang sama atau kabupaten/kota yang lain.

2) Alih fungsi/profesi guru, sesuai dengan ketentuan yang berlaku.

3) Pensiun dini, sesuai dengan ketentuan yang berlaku.

Penataan guru PNS merupakan upaya optimalisasi pemberdayaan guru PNS untuk memenuhi beban kerja minimal 24 jam tatap muka dan maksimal 40 jam tatap muka perminggu. Guru yang diprioritaskan untuk melaksanakan tugas minimum 24 jam tatap muka dan maksimum 40 jam tatap muka perminggu didasarkan pada kriteria sebagai berikut sesuai dengan bobot penilaian dari nilai tertinggi:

1. Guru bersertifikat pendidik;

2. Masa kerja tertinggi sebagai guru;

3. Pangkat dan golongan tertinggi;

4. Guru yang mengampu mata pelajaran sesuai dengan latar belakang pendidikannya;

5. Perolehan angka kredit tertinggi;

6. Tugas tambahan, dan

7. Prestasi kerja berdasarkan penilaian kinerja guru (yang dilakukan).

Selanjutnya pada mekanisme pelaksanaan tersebut, dalam proses penataan Dinas Pendidikan Kabupaten/Kota melakukan tahapan sebagai berikut:
1. Menerima dan melakukan rekapitulasi data guru PNS berdasarkan laporan hasil analisis kebutuhan guru PNS pada jenjang pendidikan TK dan SD dari seluruh UPTD Pendidikan Kecamatan di kabupaten/kota bersangkutan dengan menggunakan format yang telah ditentukan.

2. Menerima dan melakukan rekapitulasi data guru PNS berdasarkan laporan hasil analisis kebutuhan guru PNS pada jenjang pendidikan SMP, SMA, dan SMK dari seluruh kepala satuan pendidikan di kabupaten/kota bersangkutan dengan menggunakan format yang telah ditentukan.

3. Melakukan rekonsiliasi kebutuhan guru PNS bersama UPTD Kecamatan dan Kepala Sekolah SMP, SMA, dan SMK di kabupeten/kota bersangkutan.

4. Sesuai dengan kewenangannya wajib membuat perencanaan penataan dan pemerataan guru PNS antar satuan pendidikan, antar jenjang, dan antar jenis pendidikan di wilayahnya.

5. Menyampaikan hasil perencanaan sebagaimana dimaksud di atas sebagai bahan informasi kepada pemerintah provinsi paling lambat bulan Februari tahun berjalan.

6. Sesuai dengan kewenangannya, memfasilitasi/memproses pemindahan guru PNS dari sekolah yang kelebihan guru ke sekolah yang kekurangan guru dengan mengacu pada ketentuan sebelumnya.

7. Membuat laporan pelaksanaan penataan dan pemerataan guru PNS antar satuan pendidikan, antar jenjang, dan antar jenis pendidikan di wilayahnya danmenyampaikan kepada pemerintah provinsi dengan tembusan kepada Kementerian Pendidikan dan Kebudayaan paling lambat bulan Juni tahun berjalan.

Satuan pendidikan yang memiliki kelebihan guru untuk mata pelajaran tertentu dan guru yang bersangkutan tidak dapat memenuhi beban kerja minimum 24 jam tatap muka perminggu pada mata pelajaran yang sama dari satuan pendidikan lain dalam kabupaten/kota yang 
sama, maka satuan pendidikan akan menetapkan guru yang harus dipindahkan ke satuan pendidikan lain.

Penetapan guru yang harus dipindahkan didasarkan atas pertimbangan sebagai berikut:

1. Pemenuhan kebutuhan guru dalam rangka peningkatan mutu pendidikan berdasarkan penilain kinerja.

2. Pemenuhan beban mengajar minimum 24 jam tatap muka perminggu di sekolah tujuan.

3. Rasionalitas jarak, waktu tempuh, dan akses dari tempat tinggal ke lokasi satuan pendidikan baru.

Untuk menjamin tetap berlangsungnya proses pembelajaran di sekolah, maka proses pemindahan guru PNS dari sekolah yang kelebihan guru ke sekolah yang kekurangan guru, dalam satu kabupaten/kota, dilakukan pada akhir semester pada tahun berjalan. Sedangkan pemindahan guru antar kabupaten/kota baik dalam satu provinsi maupun antar provinsi, pemindahan guru harus dilakukan paling lambat pada bulan Oktober tahun berjalan.

\section{METODOLOGI PENELITIAN}

Secara umum tujuan penelitian ini adalah untuk mengidentifikasi dan mendeskripsikan penataan dan pemerataan berdasarkan beban kerja guru SMA Negeri di Tembilahan Kota Kecamatan Tembilahan Kabupaten INHIL.

Penelitian ini dilaksanakan di SMA Negeri 1 dan SMA Negeri 2 Tembilahan Kota kecamatan Tembilahan Kabupaten Indragiri Hilir. Waktu penelitian dilakukan 3 bulan setelah finalisasi proposal penelitian, yaitu pada bulan Oktober 2016.

Sekolah Menengah Atas Negeri yang ada di Tembilahan Kota Kecamatan Tembilahan
Kabupaten Indragiri Hilir terdapat 2 sekolah yang berstatus negeri, yaitu SMA Negeri 1 Tembilahan yang dipimpin oleh Bapak M. Fauzi, S.Pd dan SMA Negeri 2 Tembilahan yang dipimpin oleh Bapak Victoria, S.Pd., MM.

Metode yang digunakan dalam penelitian ini adalah penelitian yang bersifat deskriptif yaitu menggambarkan suatu keadaan yang sebenarnya.

Informan dalam penelitian ini adalah pegawai dinas pendidikan dengan inisial nama (H.M.HM, dan Drs, M.R.F, M.Pd), Pengawas dengan inisial (Drs.M) dan beberapa Kepala Sekolah dengan inisial ( M.F, S.Pd dan V, S.Pd., MM) beserta beberapa guru di SMA Negeri 1 dan guru SMA Negeri 2. Informan ini sangat berguna untuk mengumpulkan informasi agar dapat dijadikan data oleh peneliti.Beberapa teknik pengumpulan data kualitatif dalam penelitian ini adalah Wawancara, Dokumentasi,Observasi, rekam Audio, data dari buku dan data dari web.

\section{HASIL PENELITIAN}

\section{Gambaran Umum tentang Latar Penelitian}

Sekolah Menengah Atas Negeri yang terdapat di Tembilahan Kota ada dua sekolah, yaitu Sekolah Menengah Atas Negeri 1 dan Sekolah Menengah Atas Negeri 2. Sekolah MenengahAtas Negeri 1 Tembilahan berdiri pada tanggal 14 September 1967. SMA Negeri 1 Tembilahan terletak di Jalan Pendidikan. Saat ini jumlah rombel 28 dengan jumlah tenaga pendidik 58 orang. Sekolah Menengah Atas Negeri 2 Tembilahan berdiri pada tanggal 29 April 2013. SMANegeri 2 terletak di Jalan Tanjung Harapan. Saat ini jumlah rombel 18 dengan jumlah tenaga pendidik 38 orang. 
Rekapitulasi jumlah guru SMA1 Tembilahan Kota

\begin{tabular}{|c|c|c|c|c|c|c|c|}
\hline No & $\begin{array}{l}\text { Mata } \\
\text { Pelajaran }\end{array}$ & $\begin{array}{l}\text { Romb } \\
\text { el }\end{array}$ & $\begin{array}{l}\text { Jam } \\
\text { pelajara } \\
\text { n }\end{array}$ & $\begin{array}{l}\text { Jumlah } \\
\text { jam } \\
\text { pelajara } \\
\text { n }\end{array}$ & $\begin{array}{l}\text { Kebutuhan } \\
\text { guru }\end{array}$ & $\begin{array}{l}\text { Gur } \\
\text { u } \\
\text { yang } \\
\text { ada }\end{array}$ & $\begin{array}{l}\mathrm{KE} \\
\mathrm{T} .\end{array}$ \\
\hline 1 & Pend. Agama & 28 & 3 & 84 & $84: 24=3,5$ & 2 & -1 \\
\hline 2 & PPKN & & 2 & 56 & $56: 24=2,3$ & 4 & +2 \\
\hline 3 & Bahasa Indonesia & & 4 & 112 & $112: 24=$ & 4 & -1 \\
\hline 4 & Matematika & & 4 & 112 & 4,6 & 6 & +1 \\
\hline 5 & Sejarah Indonesia & & 2 & 56 & $112: 24=$ & 2 & - \\
\hline 6 & Bahasa Inggris & & 2 & 56 & 4,6 & 4 & +2 \\
\hline 7 & Biologi & & 3 & 84 & $56: 24=2,3$ & 3 & - \\
\hline 8 & Fisika & & 3 & 84 & $56: 24=2,3$ & 3 & - \\
\hline 9 & Kimia & & 3 & 84 & $84: 24=3,5$ & 4 & +1 \\
\hline 10 & Geografi & & 3 & 84 & $84: 24=3,5$ & 1 & -2 \\
\hline 11 & Sosiologi & & 3 & 84 & $84: 24=3,5$ & 2 & -1 \\
\hline 12 & Ekonomi & & 3 & 84 & $84: 24=3,5$ & 5 & -1 \\
\hline 13 & Bhs. \& Sastra & & 2 & 56 & $84: 24=3,5$ & 1 & -1 \\
\hline 14 & Jerman & & 2 & 56 & $84: 24=3,5$ & - & -2 \\
\hline 15 & Bhs. Arab & & 3 & 84 & $56: 24=2,3$ & 2 & -1 \\
\hline 16 & Penjaskes & & 2 & 56 & $56: 24=2,3$ & - & -2 \\
\hline 17 & TIK & & 3 & 84 & $84: 24=3,5$ & 2 & -1 \\
\hline 18 & Seni Budaya & & 2 & 56 & $56: 24=2,3$ & 1 & -1 \\
\hline \multirow[t]{3}{*}{19} & Muatan Lokal & & - & & $84: 24=3,5$ & 3 & - \\
\hline & $\mathrm{BK} / \mathrm{BP}$ & & & & $56: 24=2,3$ & 49 & \\
\hline & Total & & & & & & \\
\hline
\end{tabular}

Rekapitulasi jumlah guru SMA2 Tembilahan Kota

\begin{tabular}{|c|c|c|c|c|c|c|c|}
\hline No & $\begin{array}{l}\text { Mata } \\
\text { Pelajaran }\end{array}$ & $\begin{array}{l}\text { Romb } \\
\text { el }\end{array}$ & $\begin{array}{l}\text { Jam } \\
\text { pelajara } \\
\mathrm{n}\end{array}$ & $\begin{array}{l}\text { Jumlah } \\
\text { jam } \\
\text { pelajara } \\
\text { n }\end{array}$ & $\begin{array}{l}\text { Kebutuhan } \\
\text { guru }\end{array}$ & $\begin{array}{l}\text { Gur } \\
\mathrm{u} \\
\text { yang } \\
\text { ada }\end{array}$ & $\begin{array}{l}\text { KE } \\
\text { T. }\end{array}$ \\
\hline 1 & PPKN & 18 & 3 & 54 & $54: 24=$ & 2 & - \\
\hline 2 & Agama & & 2 & 36 & 2,25 & 2 & +1 \\
\hline 3 & Bahasa Indonesia & & 4 & 72 & $36: 24=1,5$ & 2 & -1 \\
\hline 4 & Bahasa Inggris & & 4 & 72 & $72: 24=3$ & 2 & -1 \\
\hline 5 & Sejarah Nasional & & 2 & 36 & $72: 24=3$ & 1 & - \\
\hline 6 & Pend. Jasmani & & 2 & 36 & $36: 24=1,5$ & 1 & - \\
\hline 7 & Matematika & & 3 & 54 & $36: 24=1,5$ & 1 & -1 \\
\hline 8 & Fisika & & 3 & 54 & $54: 24=$ & 2 & - \\
\hline 9 & Biologi & & 3 & 54 & 2,25 & 3 & +1 \\
\hline 10 & Kimia & & 3 & 54 & $54: 24=$ & 2 & - \\
\hline 11 & Ekonomi & & 3 & 54 & 2,25 & 1 & -1 \\
\hline 12 & Sosiologi & & 3 & 54 & $54: 24=$ & - & -2 \\
\hline 13 & Geografi & & 2 & 36 & 2,25 & 1 & - \\
\hline 14 & TIK & & 2 & 36 & $54: 24=$ & - & -1 \\
\hline 15 & Pend. Seni & & 3 & 54 & 2,25 & 2 & - \\
\hline 16 & $\mathrm{BP} / \mathrm{BK}$ & & 2 & 36 & $54: 24=$ & 1 & - \\
\hline 17 & Prakarva/ & & 3 & 54 & 2,25 & - & -2 \\
\hline \multirow[t]{10}{*}{18} & Keterampilan & & 2 & 36 & $54: 24=$ & - & -1 \\
\hline & Bhs.Asing Lain & & - & & 2,25 & 23 & _ \\
\hline & Total & & & & $36: 24=1,5$ & & \\
\hline & & & & & $36: 24=1,5$ & & \\
\hline & & & & & $54: 24=$ & & \\
\hline & & & & & 2,25 & & \\
\hline & & & & & $36: 24=1,5$ & & \\
\hline & & & & & $54: 24=$ & & \\
\hline & & & & & 2,25 & & \\
\hline & & & & & $36: 24=1,5$ & & \\
\hline
\end{tabular}




\section{Temuan Penelitian}

Temuan penelitian berdasarkan wawancara, dokumentasi, dan observasi. Data yang digunakan dalam penelitian ini adalah data terakhir tahun 2016 semester ganjil tahun pelajaran 2016/2017. Penyajian temuan ini menurut sub fokus penelitian.

Hasil temuan penelitian terhadap perencanaan penataan dan pemerataan berdasarkan beban kerja guru SMA di Tembilahan Kota yang didapat dari hasil wawancara, yaitu wawancara yang dilakukan dengan sekretaris dinas pendidikan, dan beberapa kepala sekolah SMA Negeri di Tembilahan Kota, sebagai berikut:

“Awal perencanaan penataan dan pemerataan berdasarkan beban kerja guru SMA di Tembilahan Kota sebagai berikut: a. Membuat konsep penataan dan pemerataan, b. Sosialisasi program penataan dan pemerataan, dan c. Menyediakan peta guru yang menginformasikan tentang kekurangan ataupun kelebihan guru.” (Sekretaris Dinas Pendidikan).

"Penataan dan pemerataan sebenarnya memiliki produk hukum yang berbentuk peraturan bupati terkait penataan dan pemerataan itu. Selain itu, dalam perencanaan biasanya ada sosialisasi program penataan dan pemerataan. Nah, di situlah dijelaskan tentang konsep penataan dan pemerataan, sangsi yang ada, peta yang menginformasikan kebutuhan guru, baik untuk kelebihan ataupun kekurangan guru.” (Kepala Sekolah SMA 1).

"Penataan dan pemerataan kalau setiap tahun penataan berapa kebutuhan guru sesungguhnya yang diperlukan. Sehingga 24 jam terpenuhi. Kami juga perlu berkonsultasi kepada pihak dinas pendidikan. Sengaja kami membuat analisis dari kebutuhan guru supaya sesuai dengan bidang studi yang diajarkannya. Kami rutin mengerjakan di sekolah itu. Pertemuanpertemuan, baik dari dinas pendidikan tentang pernyataan penataan dan pemerataan." (Kepala Sekolah SMA Negeri 2).

Dari hasil temuan di atas, baik dari dinas pendidikan maupun dari beberapa kepala sekolah memberi penjelasan bahwa pada tahap perencanaan penataan dan pemerataan beban kerja guru SMA Negeri di Tembilahan Kota sudah dilaksanakan. Terlihat dari isi wawancara di atas, bupati juga berperan dalam pembuatan produk dalam bentuk peraturan. Tidak hanya bupati yang berperan dalam perencanaan penataan dan pemerataan ini. Namun, dalam hal perencanaan penataan dan pemerataan ini, dinas pendidikan dan kepala sekolah juga terlibat dalam mengimplentasikan kebijakan yang ada.

\section{SIMPULAN}

Berdasarkan hasil penelitian yang dilakukan secara kualitatif, maka dapat diambil kesimpulan sebagai berikut:

- Perencanaan program penataan dan pemerataan berdasarkan beban kerja guru SMA Negeri di Tembilahan Kota Kecamatan Tembilahan Kabupaten Indragiri Hilir telah dilaksanakan.

- Pada tahap pelaksanaan penataan dan pemerataan berdasarkan beban kerja guru SMA Negeri di Tembilahan Kota, Dinas pendidikan dan kepala sekolah SMA Negeri memilihi hubungan kerjasama yang baik.

- Hasil pelaksanaan program penataan dan pemerataan berdasarkan beban kerja guru SMA Negeri di Tembilahan Kota Kecamatan Tembilahan Kabupaten Indragiri Hilir sudah berjalan dengan baik.

\section{DAFTAR PUSTAKA}

Abdul, Wahab Solichin. 2004. Analisis Kebijaksanaan, Dari Formulasi Ke Implementasi Kebijakan Negara. Jakarta: Bumi Aksara.

Arikunto, Suharsimi. 2005. Manajemen Penelitian. Jakarta: Rineka Cipta.

Ariesto, Hadi Sutopo dan Adrianus Arief. 2010.Terampil Mengolah Data Kualitatif Dengan NVIVO. Jakarta: Prenada Media Group.

Bugin, Burhan. 2009. Penelitian Kualitatif. Jakarta: PT. Fajar Interpratama Offset. Depdiknas. 2008. Kamus Besar Bahasa 
Indonesia. Jakarta : PT.Gramedis Pustaka Utama. 2013. Standar Nasional Pendidikan: (PP No.32 Tahun 2013) dilengkapi dengan PP No. 19 Tahun 2005. Jakarta: Sinar Grafika. 2013. Undang-Undang Pendidikan : Undang-Undang Pendidikan PP No. 32 Tahun 2013 Tentang Standar Nasional Pendidikan (S.N.P). Yogyakarta: Pustaka Mahardika.

Fakhrurrozi. 2015. Tesis. "Implementasi Kebijakan Penataan dan Pemerataan Guru SMP Di Kabupaten Siak”. Pekanbaru : UR.

Harsono, Hanifah. 2002. Implementasi Kebijakan dan Politik. Jakarta: Grafindo Jaya.

Hood, Christopher. 1991. A Public Management for All Season; Public Administration Vol. 69: Royal Institude of Public Administration: Spring.
Ismawati, Esti. 2011. Metode Penelitian Pendidikan Bahasa dan Sastra. Surakarta: Yuma Pustaka.

Mazmanian, Daniel H., dan Paul A. Sabatier. 1983. Implementasi and Public Policy. New York: Harper Collins.

Meter, Donald Van, dan Carl Van Horn. 1975. The Policy Implementations Process: A Conceptual Framework dalam Administration and Society 6 1975. London: Sage.

Miles, M. B dan Huberman, A. M. 1984. Qualitative Data Analysis: A Sourcebook of New Methods. California: Sage

Nurmianto, Eko. 2003. Ergonomi Konsep Dasar dan Aplikasinya. Surabaya: Guna Widya.

Rialis, Muhammad. 2015. Tesis. "Pemetaan dan Pemerataan Berdasarkan Beban Kerja Guru SMP Di Kecamatan Kampar.

Setiawan, Guntur. 2004. Implementasi dalam Birokrasi Pembangunan. Bandung: Remaja Rosdakarya Offset. 